\title{
Self-Regulated Learning in Designing Explorative Learning Tools Among Mathematics Pre-service Teachers through Explorative Module
}

\author{
Indhira Asih Vivi Yandari $^{1,}{ }^{,}$, Hepsi Nindiasari $^{1}$, Etika Khaerunnisa ${ }^{1}$, \\ Aan Subhan Pamungkas ${ }^{1}$, Karso $^{2}$, Nurjanah ${ }^{2}$ \\ 1) Pendidikan Matematika, Universitas Sultan Ageng Tirtayasa, Serang, Indonesia \\ 2) Pendidikan Matematika, Universitas Pendidikan Indonesia, Bandung, Indonesia
}

\begin{abstract}
This study is back grounded by the importance of self- regulated learning in mathematics pre-service teachers. By possessing self-regulated, students will be able to evaluate learning process, set learning target, arrange the strategy in learning to achieve the goal, search relevant supporting materials for the lectures and show self efficacy. One task which play a role to make students successful to become professional teacher is by creating explorative learning tools. The development of this explorative tools very support learning activity process in class. This study aims to see to what extent self-regulated learning among students in developing explorative learning tools. The method of study is experimental quasi by treatment which is initiated with explorative learning and then explorative module learning is given to one class. The subjects in this study are students of mathematics department with total of 21 students, consist of 4 males and 17 females. Quantitative analysis was performed using the average difference test. The result of study shows that the average of students' self-regulated learning after treatment is in good category and there is significant difference in self regulated learning before and after treatment. It can be concluded that these treatment give good contribution to develop students' self-regulated learning.
\end{abstract}

Keywords: Self regulatory learning, explorative, Pre-service teachers,
explorative module

\section{INTRODUCTION}

Self regulated learning is one important factor in learning. Self regulatory is an ability to direct and control our self in thinking and act, and not depend on the other people emotionally [1]. Self regulated learning contain the meaning of learning based on the ability possessed. Self regulated learning is an ability to monitor own ability and human personality hard effort [2]. Self regulated learning means that students have self consciousness to learn, capable to self determine the steps which should be taken in learning, capable to obtain learning resource by themselves, and doing evaluation activity and reflection on learning activity which had been done. Students who have high self regulated learning tend to learn better, capable to monitor, evaluate and regulate their learning schedule effectively. Self regulated learning is so important to be possessed by students, so development of self regulated learning should be strived for, in order to support the success of lectures process. Self regulated learning has high correlation with the success of their students [3]. Sellf regulated person will show explorative behavior, capable to take decision, self confident and creative [4].

*indhira_1969@untirta.ac.id 
Self regulated learning support the process of task accomplishment. Self regulated learning as designing and self monitoring process thoroughly toward cognitive and affective process in accomplishing an academic task [2]. In lectures, of course as students of pre-service teacher need self regulation in solving their academic tasks. One task which play role to make students successfully to become a professional teacher is by making learning tool. Learning tool designed is aimed to be able to develop all potencies in students. One alternative which can be arranged is explorative learning tool.

Explorative learning offer the opportunity to students to broaden their knowledge by using process and skill and connect prior knowledge with their learning experience to solve the problem by involving students in the process of problem solving. Through exploration activity, students can find mathematical process in a such way so they experience themselves, capable to create a hypothesis (conjecture), and then search the answer to conjecture students make through observation activity [1].

Furthermore, Explorative is an approach which aims to delve out the ideas, arguments and the methods which are differ from students through some open-ended questions and commands so it can enable students to understand a concept and solution of problems [5]. Through explorative activity, students are expected can enhance their ability in imagining, intuiting, divergent thinking, producing original work, predicting and conjecturing, trial and error [6].

The essence of that explorative learning is contained in explorative learning stage. According to National Education Department, explorative learning stage comprise: 1) the presentation of exploration problem; 2) data or information collection; 3) data analysis, 4) drawing conclusion [7]. NCTM also give some important things to be given attention to create mathematical explorative activity which is effective, namely: 1) Using real objects (physical); 2) using various topics which is interesting and relevant; 3) question; 4) writing activity; 5) cooperative and collaborative group; 6) listening; 7) assessing [8].

By the strength of that explorative learning, it is hoped that a teacher can design meaningful learning for students by developing explorative learning tool so high order thinking ability can be realized, and students' mathematics learning result is more enhanced. In order that teachers are able to design meaningful learning, the guidance should be given since students study in campus. In this Institution, students need to be trained in how to design active learning supported by learning tools among other are explorative Student Worksheet and learning scenario. To support the arrangement of explorative learning tools, of course students should be accustomed with explorative learning activity in learning classroom. So, by experience directly explorative learning process, students are expected to be able to create explorative learning ideas for learning in school.

In explorative learning implementation, students are confronted by a problem. By the problem given in the initial learning, students are expected to be able to utilize the knowledge and learning experience possessed before so they are able to generate creative ideas, to identify the problem as initial process to solve the problem given. Explorative learning facilitate students to collect data and information to answer the problem posed through discovery by investigating, search relevant information, and make generalization from investigation result. After exploration process is implemented, students are directed to apply the concept which had been obtained by confronted with the task to make explorative learning tools.

Seeing explorative learning process is tightly related to investigation activity, contain challenging learning tasks and students take bigger role in their learning responsibility. Therefore, it is supposed that explorative learning can give good contribution to self regulated learning among mathematics pre-service teachers. So, the *indhira_1969@untirta.ac.id 
formulation of problem in this study is how does self regulated learning of mathematics pre-service teachers in designing explorative learning tools through explorative module?

\section{METHOD}

This study is experimental quasi with modified pretest-posttest group design. In this study, students are given treatment in the form of explorative learning before initial scale of self regulated learning is given, after initial scale, the treatment is given in the form of explorative module and finally students are final scale of self regulated learning. The subjects in this study are students of mathematics department with total of 21 students, consist of 4 males and 17 females.

The instrument used in this study is self regulated learning scale. This scale consist of 40 statements. Based on the response given by students, next the percentage of achievement average of self regulated learning in each aspect is determined.

\section{RESULT AND DISCUSSION}

Self regulated learning in this study consist of some components, namely initiative, diagnose the needs, set the target, monitor, view the difficulty as challenge, utilize and find relevant learning resource, choose and apply the strategy, evaluate the process and learning outcome, and self ability. The mean score from self regulated learning for each aspect is obtained based on students' response. Recapitulation of self regulated learning scale can be seen in Table 2.

Table 2. Description of Self-Regulated Learning Data

\begin{tabular}{cccc}
\hline \multirow{2}{*}{ No } & \multicolumn{1}{c}{ Aspect } & \multicolumn{2}{c}{ Average (\%) } \\
\cline { 3 - 4 } & & Initial Scale & Final Scale \\
\hline 1 & Learning initiative & 60,19 & 72,38 \\
\hline 2 & Diagnose learning need & 60,00 & 70,95 \\
\hline 3 & Set learning target & 51,19 & 59,29 \\
\hline 4 & Monitor and control learning & 50,10 & 55,81 \\
\hline 5 & See difficulty as challenge & 60,76 & 70,10 \\
\hline 6 & Utilize and search relevant learning resource & 50,71 & 57,38 \\
\hline 7 & Choose and apply strategy & 55,56 & 58,41 \\
\hline 8 & Evaluate the process and learning outcome & 47,94 & 55,87 \\
\hline 9 & Self Concept & 61,22 & 75,10 \\
\hline \multicolumn{2}{r}{ Total Average } & 56,05 & 65,26 \\
\hline
\end{tabular}

From Table 2 above, it is known that the initial achievement of students' self regulated learning is $56.05 \%$ and fall in enough criteria, and the final achievement of students' self regulated learning is $65.26 \%$ and fall in good category. From quality aspect, it is seen that there is enhancement of self regulated learning from enough category to good category.

The following is diagram of comparison between initial and final achievement of students' self regulated learning for each aspect.

*indhira_1969@untirta.ac.id 


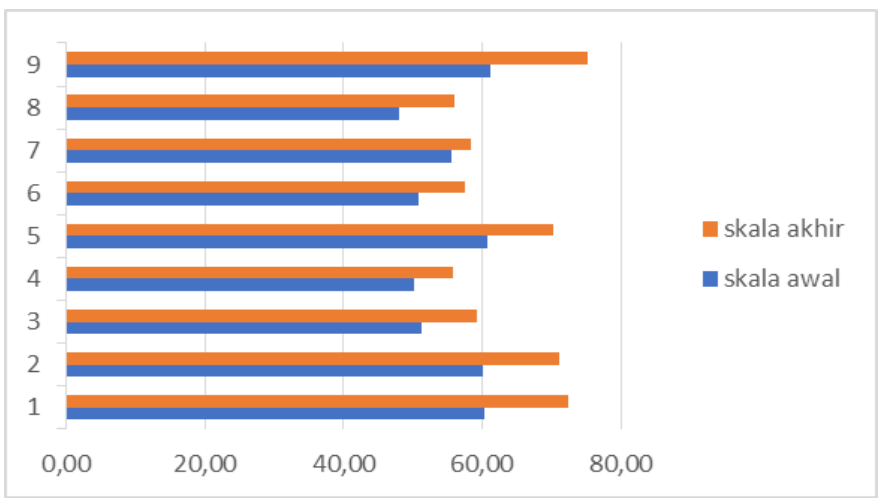

Fig. 1. The Achievement of Self-Regulated Learning for Each Aspect

From the figure above, it can be seen that there are some aspects in self regulated learning which is enhanced quite high, namely learning initiative, diagnose learning needs, see difficulty as challenge and self ability. These four aspects fall in good category. Whereas for achievement in following aspects: set learning target, monitor and control learning, utilize and search relevant supporting materials, choose and apply learning strategy and evaluate process and learning outcome fall in good category. Whereas for achievement in aspects: determine learning target, monitor and control learning, utilize and search relevant supporting material, choose and apply learning strategy and evaluate the process and learning outcome fall in enough category. These four aspects are less developed well even though receive different treatment with initial treatment.

The highest achievement both in initial scale and final scale is achieved in aspect of self ability, that is $61.22 \%$ for initial achievement and 75.10 for final achievement, whereas this shows that aspect is not develop well after students receive the treatment, that is, explorative learning with module.

Based on explanation above, it shows that descriptively the final achievement of self regulated learning is higher than initial achievement, but this need to be proved inferentially whether or not the initial and final achievement is differ before and after treatment. The following is the result of paired average difference test.

Table 3. Paired Average Difference Test

\begin{tabular}{ccc}
\hline $\mathrm{t}$ & Df & Sig. (2-tailed) \\
\hline$-8,057$ & 20 & 0,000 \\
\hline
\end{tabular}

Significance value of 0.000 is less than 0,05 . This shows that there is difference in students' self regulated learning before and after given the treatment. This assert that the treatment give big contribution toward development of students' self regulated learning.

There are some findings that explorative learning with or without module cause students have good self regulated learning, among other is that explorative learning is based on problem and students are active participant in their own learning.

In initial learning, the lecturer present exploration problem to students. This presentation stage is the key of whether or not explorative learning is successful. With interesting exploration problem, it is hoped that students are motivated to conduct investigation. Lecturer needs to present problem situation to students as interesting as possible, usually by providing something which can be seen, felt or touched will arouse interest and motivation to investigate, and the problem given can encourage students to initiate learning, diagnose learning needs, set the target/the goal of learning, monitor, *indhira_1969@untirta.ac.id 
regulate and control learning, see difficulty as challenge; utilize and search the relevant supporting material to solve the problem; choose and apply learning strategy; evaluate process and learning outcome; self concept [9]. These abilities are known as self regulated learning.

One example of explorative learning which is implemented in this study is following. The First stage is present exploration problem, in which students are directed to conduct investigation toward a learning media in one of mathematical concepts. With learning media given, it can grow students' learning initiative and they see difficulty as challenge. It is seen when learning which is indicated by students' initiative to do manipulation directly toward media given and all students involvement in manipulating that media. The second stage is data and information collection, in which students are asked to identify whether the media given is included in media hands on activity category based on its characteristics. In this stage, students ability in utilizing learning source is seen, because students are actively searching some information from internet and handbook to finish the task. The third stage is students are asked to do analysis toward the existing data to support the arrangement of students worksheet based on that hands on activity, and continued by arrangement of learning scenario which can be used by teacher in class. In this stage, indicator of self-regulated learning is seen, in which all students have initiative to share the task with their group members, capable to finish the task with systematical procedure, utilize the relevant source, determine learning strategy to finish the task. The fourth stage is present the result report and draw the conclusion, in which students are asked to present students worksheet and learning scenario which had been arranged, by comparing it with the task in another group, whether or not students worksheet and learning scenario which had been arranged is explorative. This stage can grow students ability in evaluating the process and learning outcome through question answer in group presentation setting.

The importance of learning which is began by the problem is also revealed by Conney which stated that teaching problem solving then students will become more analytical in making decision in their life, autonomous in solving the problem, because students will be skillful about how to collect relevant information, to analyze information and to realize how important to study again the result obtained. Besides, the problem which is given also play role to give good opportunity to broaden thinking because when students try to solve the problem in class, students construct their knowledge actively.

The following is learning which is implemented by lecturer and students in explorative learning through explorative module in concept of designing learning tool. There are some activities which are done by students in explorative learning through module. Students do some series of activities which are suited with explorative module that is in first activity in the form of students activity in distinguishing question and command. The second activity is examine the question of first activity (identify open ended, productive and imaginative question). In the third activity, students make higher order question based on worksheet given. In the forth activity, students examine the result of third activity. In fifth activity, students identify the component of worksheet given. Then it is continued by reflection stage which is guided by lecturer, and student draw conclusion.

Another finding show that the factor which make students' self regulated learning become good is learning process which is done cooperatively or in group. In its implementation, students can enhance their learning initiative because each member have same responsibility for the success of their group, seeing learning difference in each member so they are able to decide the right strategy for themselves. Students in group are triggered to be able to set the working target in group so they can design learning tools.

*indhira_1969@untirta.ac.id 
Self regulated learning for mathematics pre-service teachers is important to be possessed, because by this self regulated learning they can develop their knowledge of pedagogical competence more deeply [10]. Self regulated learning possessed by teacher finally can create mathematics learning process which is meaningful for students [10].

\section{CONCLUSION}

Based on result of study, it can be concluded that students' self regulated learning after given treatment is categorized good. There is difference in the initial and final self regulated learning among students before and after treatment. It means that the treatment given give good contribution in developing students' self-regulated learning. This conclusion is seen from achievement of percentage of self-regulated learning in each aspect measured. Besides, based on result of average difference test, it shows that there is difference in self-regulated learning before and after treatment.

Based on result of study and the importance of students' self-regulated learning, then lecturer needs to develop learning activity which can enhance this aspect. Particularly for the aspect which had not been developed well, that is, in setting learning target, monitoring and controlling learning, utilizing and searching relevant supporting material, choosing and applying learning strategy and evaluating the process and learning outcome.

\section{References}

1. Sumarmo, Utari. (2004). (Self-regulated learning: What, Why and How is it developed in Students. (online). Available: Kemandirian-belajar-mat-des-06-new.pdf. (13 mei 2012).

2. Sukirwan. (2008). Explorative Approach Activity to Enhance Mathematical Reasoning and Connection Ability of Elementary School Students: Quantitative (Thesis in Postgraduate School, Indonesia University of Education).

3. Darr, C dan Fisher, J. (2004). Self Regulated Learning in Mathematics Class. (online). Available : www.arb.nzcer.org.nz. (16 Juni 2017).

4. Kramarski, B \& Gutman, M. (2006). How can self-regulated learning be supported in mathematical E-learning environments?. Journal of Computer Assisted Learning. Online. Volume 22, Issue 1 February 2006 Pages 24-33. Tersedia : http://onlinelibrary.wiley.com/doi/10.1111/j.1365-2729.2006.00157.x/abstract. (15 Juli 2017).

5. Monks, F.J., dkk. (1999). Psychology of Development Introduction in Its Various Parts Yogyakarta: Gadjah Mada University.

6. Rohaeti, E. (2008). Learning with Exploration Approach to Develop Mathematical Critical and Creative Thinking Ability of Junior High School Students : Quantitative (Dissertation in Postgraduate School, Indonesia University of Education).

7. Depdiknas. (2003). S Assessment Standard of Mathematics Textbook . Jakarta: Pusat Perbukuan.

8. Shadiq, F. (2011).. Mathematics exploration in Elementary School/MI: Its Example, Definition and Strenght (online). Available on : $h$ ttp://fadjarp3g.files.wordpress.com/2011/03/10eksplorasidisd_fasilitator_.pdf. (16 Juni 2017).

9. Arends, R. (2008). Learning to Teach . Yogyakarta: Translation, Pustaka Pelajar.

10. Kramarski, B \& Michalsky, Tova. (2010). Preparing preservice teachers for selfregulated learning in the context of technological pedagogical content knowledge. Journal Learning and Instruction. Online.Volume 20, Issue 5, October 2010, Pages 434-447. Tersedia : http://dx.doi.org/10.1016/j.learninstruc.2009.05.003. (15 Juli 2017).

*indhira_1969@untirta.ac.id 